\begin{tabular}{|c|c|}
\hline AUTHORS & $\begin{array}{l}\text { Oksana Polinkevych (D) https://orcid.org/0000-0001-6924-7296 } \\
\mathbb{R} \text { http://www.researcherid.com/rid/E-6319-2017 } \\
\text { Ryszard Kamiński (D https://orcid.org/0000-0001-5110-8300 } \\
\mathbb{R} \text { http://www.researcherid.com/rid/l-4715-2018 }\end{array}$ \\
\hline ARTICLE INFO & $\begin{array}{l}\text { Oksana Polinkevych and Ryszard Kamiński (2018). Corporate image in } \\
\text { behavioral marketing of business entities. Innovative Marketing , 14(1), 33-40. } \\
\text { doi:10.21511/im.14(1).2018.04 }\end{array}$ \\
\hline DOI & http://dx.doi.org/10.21511/im.14(1).2018.04 \\
\hline RELEASED ON & Thursday, 10 May 2018 \\
\hline RECEIVED ON & Monday, 02 April 2018 \\
\hline ACCEPTED ON & Monday, 07 May 2018 \\
\hline LICENSE & $\begin{array}{l}(c) \text { EY } \\
\text { This work is licensed under a Creative Commons Attribution } 4.0 \text { International } \\
\text { License }\end{array}$ \\
\hline JOURNAL & "Innovative Marketing " \\
\hline ISSN PRINT & $1814-2427$ \\
\hline ISSN ONLINE & $1816-6326$ \\
\hline PUBLISHER & LLC "Consulting Publishing Company "Business Perspectives" \\
\hline FOUNDER & LLC "Consulting Publishing Company "Business Perspectives" \\
\hline
\end{tabular}

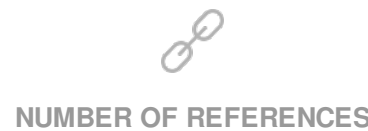

22

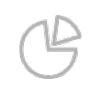

NUMBER OF FIGURES

4
蝗

NUMBER OF TABLES

0

(c) The author(s) 2021. This publication is an open access article. 


\title{
Corporate image in behavioral marketing of business entities
}

\begin{abstract}
Nowadays, the development of an effective corporate image model is a topical issue. Under increasing competition in many economic spheres, forming the company's reputation and meeting the growing needs of consumers are especially noteworthy. The purpose of the article is to develop a set of marketing measures that would contribute to the formation of a positive corporate image of business entities and support it in the long run. The relationship between the research subject and the consumer needs is highlighted. The article deals with the features of behavioral economics and general approaches to shaping the corporate image. It is proposed that business entities should take into account five target segments, including clients, suppliers, shareholders, employees, and intermediaries when forming a positive corporate image. It is noted that each of these subjects is an "econ" who does not make rationalistic decisions, but places emphasis on spontaneity and emotionality. It is also noted that it is difficult to predict the situation of forming a positive corporate image of business entities. The results of this article can be used in further research and taken into account when creating a corporate image of an enterprise.
\end{abstract}

Keywords: behavioral economics, corporate image, corporate culture, marketing strategy, loyalty.

JEL Classification: G39, G40, M30, M31.

Received on: $2^{\text {nd }}$ of April, 2018.

Accepted on: $7^{\text {th }}$ of May, 2018.

\section{Introduction}

Behavioral economics, as a separate direction of the economy, arose not so long ago - during the last three decades. It is based on a psychological aspect. Traditional economics considers a person as an individual with logical thinking to make informed decisions based on the information available. Due to this, he maximizes his own profit and minimizes the risk level. It is a rational behavior, upon which demand and supply models, business cycles, inflation, etc., are built. However, psychological aspect of a person, namely feelings, emotions, instincts, errors, dependencies, etc., is not taken into account. Thus, a person, as a consumer and producer of public goods, can act unconventionally, irrationally. Marketing is implemented in marketing behavior models. It is considered in the narrow sense as a corporate marketing management, which is based on the development, implementation and maintenance of communication standards that promote the comprehensive development of enterprises and personnel. However, broadly, this term also includes market research, a model of employee behavior, customer group management based on marketing principles, and maintaining a positive image of business entities (Peter, 2012).

The corporate image has a significant influence on the economic activity of an enterprise. The economic agents' assessment and perception of

(C) Limited Liability Company "Consulting Publishing Company "Business Perspectives", 2018.

Oksana Polinkevych, Dr. of Economics, Professor, Head of the Department of Economics, Safety and Innovative Activity of an Enterprise, Lesya Ukrainka Eastern European National University, Ukraine.

Ryszard Kamiński, Dr. of Economics, Professor, Head of studies "Management and Business Law", Adam Mickiewicz University in Poznan, Poland. certain actions of the firm's management is a key aspect of the company's marketing policy. The concept of "image" has many different interpretations and there is no unified approach to its methodology. Therefore, it is impossible to develop a universal model of corporate image. For example, some scientists highlight the emotional and rational component of the image. The emotional component includes: design, quality of advertising, sponsors, availability of information on the company activities. The rational component includes: product assortment, its quality, level of service, customer service, working conditions and organizational culture. Consequently, behavioral economics becomes more and more relevant taking the psychological aspect of a person into account.

In the $21^{\text {st }}$ century, the following becomes more and more popular: discount systems distribution, events, drawing prize contracts on special terms, special terms of consumer lending, long-term cooperation, the organization of joint presentations, leisure, conferences, the formation of a club or other thematic institutions, a system of club discounts, the use of various leisure activities not only for employees, but also for their families, the system of awarding according to work in non-financial form, the introduction of seminars, excursions, conferences, joint financing of large projects, social adaptation, and the establishment of effective interaction between the authorities and a corporation.

\section{Literature review}

The founders of the behavioral economics American psychologists Daniel Kahneman, the Nobel Prize winner in economics in 2002, and Amos Tversky (the article entitled Prospect Theory: 
An Analysis of Decision under Risk was published in Econometrica in 1979) (Kahneman, 1979) pay attention to the drawbacks of the traditional economy.

The authors have shown that people in many cases are not inclined to act in accordance with the neoclassical economics requirements and often subject to irrational behavior. They also came to the conclusion that the economy and the market, as one of its components, is the result of human decisions. People's decisions are always characterized by uncertainty and are always risky. In modern science, the ideas of behavioral economics have become widespread and are being explored by scientists from many countries. Dan Ariely, a professor of behavioral economics at the Massachusetts Institute of Technology, is the most famous of them. He found that irrational behavior is not chaotic. It is subject to certain models and therefore quite predictable - at least in statistical terms (Ariely, 2010).

In 2017, Richard Thaler, a professor at the University of Chicago, continued the study of behavioral economics and became the Nobel laureate. Thaler said that psychology should be taken into account when making economic decisions. One of Thaler's first contributions to economic science was the discovery and analysis of the "endowment effect", according to which "people are inclined to appreciate the things that they already possess". At the same time, for the overestimated valuation of goods, the very fact of possession is important. And it does not matter whether historical attachment to the subject of evaluation has been formed. The effect of ownership affects economic relations. It can easily explain the tendency of most people to maintain the status quo both in politics and in business, despite high losses. That is, economic mobility of the population can be considerably limited, business models of companies are inert, and the political choice can for decades revolve around "familiar faces". Thaler has proved that people are economic agents. According to Thaler, classic models are simple, because rational and selfpossessed utility maximizers live in them. He calls them "econs". Econs, unlike humans, always make informed decisions, have no bad habits and are devoid of passion, which results in different consequences through the lens of economics. Ekon does not understand the idea of a gift in a real form, but understands it in money form. In the world of econs, there is no inefficient redistribution of resources, liquidity problems, bubbles in the asset market, mortgage booms, catastrophic financial crises. Each of our economic choices may not be the best because there is a large amount of information, which is time-consuming to process
(Thaler, 2015). Since 1979, Thaler, together with Amos Tversky and Daniel Kahneman, introduced the concept of "mental reporting", which consists in primitivization (simplification) of financial decision making. Kahneman has revealed a number of principles that irrational human behavior follows. He proposed two systems of thinking: "slow" and "fast". The first system is responsible for analyzing large volumes of information, examining emerging problems, while the "fast" one is responsible for making instant decisions and is based on stereotypes, established opinions and is often perceived as intuition. In practice, economic agents make consuming decisions quickly, without taking into account all factors under the influence of irrational impulses that can substantially and systematically reject the result from the optimal one. According to classical economics, such behavior is meaningless, whereas behavioral finances and life itself point to the opposite. Research by Thaler et al. is widely used by marketers, especially in e-commerce. Various systems of bonuses and discounts, electronic accounts for replenishment, free trial versions are based on the weaknesses of human psychology in relation to their own funds and in terms of saving and consumption. In criticizing the classics, Thaler did not at any time reject the multi-year achievements of economic science, believing that the models of the neoclassicists are a great starting point for more realistic economic models that help create a behavioral economy. Thaler explained the causes of anomalies in the financial markets by the psychological factors, such as the tendency of investors to reassess their own strategy and underestimate the risks during the general euphoria on the market. Instead, during "bearish trends", even professional stockholders lose capital because they tend to hold stocks in their trading portfolio longer than they should in the hope of restoring prices. The essence of the concept of "pushing" is that there is no need for excessive barriers that stop econs in making decisions. An American scientist has shown how to use the endowment effect, manifested in the inertia of our decisions, as a "push" for economic policy. Thaler is a co-author of bestsellers such as Nudge: Improving Decisions on Health, Wealth, and Happiness (2008) and Misbehaving: The Making of Behavioral Economics (2015), which clearly illustrated why human behavior is contrary to traditional economic logic, and what it results in (Kornyliuk, 2017).

Despite the considerable work performed by scientists, an aspect such as image management of corporations through behavioral marketing is not sufficiently considered. Particular attention should 
be given to approaches of the corporate image formation, its components and factors that have the greatest impact on it.

Mostafa, Lages, Shabbir, and Thwaites (2015) analyzed formation of consumer corporate image focusing on how an enterprise can effectively deal with customer complaints taking into consideration factors such as compensation, speed of response, apology, problem solving and explanation. Also, the importance of customer service quality was emphasized by Botha (2016). The author considered the interconnection between corporate culture, customer service and organizational performance.

To form a positive corporate image, humorous marketing activities can be implemented. Hashem (2017) scrutinized the influence of humor advertisement on airline customers and found out that aggressive humor has most effect on customer mental image. To achieve a good result in the creation of humorous campaign, a company should primarily be oriented towards consumers, while feedback from them is vital.

Not only humor can be used in corporate image promotion. In order to achieve marketing competitiveness, corporate music can be used. Yong (2017) analyzed how music can enhance the internal cohesion of a company and act as a promotional tool.

Sallam (2016) investigated the influence of the corporate image on the sharing positive word of mouth, purchase decisions and customer satisfaction in general.

In image building, it is vital to create a strong and recognizable brand. Latif, Islam, Noor, Mohamad, and Kongsompong (2016) have described the framework of forming brand image as follows: brand awareness, resonance, association, superiority, affection, corporate social responsibility, management and advertisement. Using CSR activities in building a brand image was studied by Richards, Thomas, Randle, and Pettigrew (2015). It may include different programs in categories such as: environment, community, partnerships, consumer responsibility, diversity, indigenous and diversity.
Ki-Han Chung, Ji-Eun Yu, Myeong-Guk Choi, and Jae-Ik Shin (2015) analyzed corporate social responsibility factors that influence customer loyalty and forming a strong reputation, presented the relationship between corporate image and CSR. The study focused on philanthropic, ethical, economic, legal responsibility, consumer protection and environmental contribution.

Korzh, Gaievskyi, and Hurdzhyian (2017) proposed a model for evaluating the marketing performance of an enterprise based on sales revenue index, paying attention to image-building, customer loyalty and purchasing intention level. Kehinde (2012) analyzed influence of four factors (productivity of an organization, longevity, effectiveness and efficiency) on organizational culture and corporate image. The author proposed an approach for an organizational development strategy that based on elements such as: resources, visions and missions, their influence on cultural element and then on image.

Van Heerden (1999) highlighted that positive image may be achieved only by taking into account aspects such as employee behavior and customer service. He claimed that corporate personality determines corporate identity and this in turn creates corporate image. The author designed a corporate image process model that considered behavioral, visual cues and marketing effects created by corporate image.

\section{Aims}

The purpose of the research is to develop a set of marketing activities that would contribute to the formation of positive corporate image of business entities and supporting it in the long run.

\section{Results}

In order to offer own corporate image structure with the conditions of behavioral marketing, it is necessary to know more about other popular models. The model by LeBlanc and Nguyen (1996) is worthy of special attention. It is based on emotional and functional attributes. Emotional part includes managerial reputation and corporate identity while functional one is focused on qualitative and quantitative characteristics such as service offering and physical environment (Figure 1). 


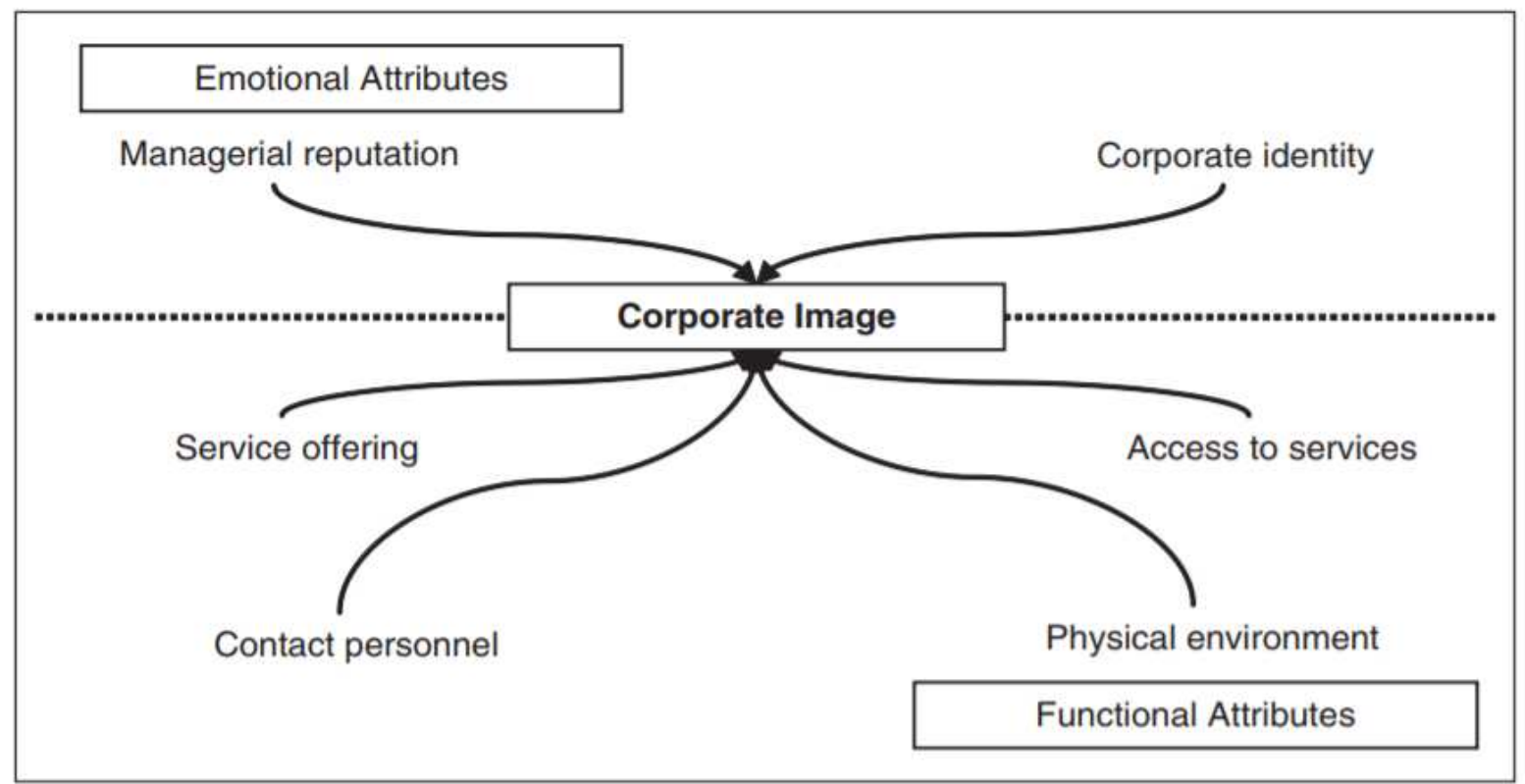

Fig. 1. The corporate image model by LeBlanc and Nguyen

Source: LeBlanc and Nguyen (1996).

Later, this model was specified by Tubillejas, functional attributes and their measurement were Cuadrado, and Frasquet (2011). In their research deeply analyzed (Figure 2).

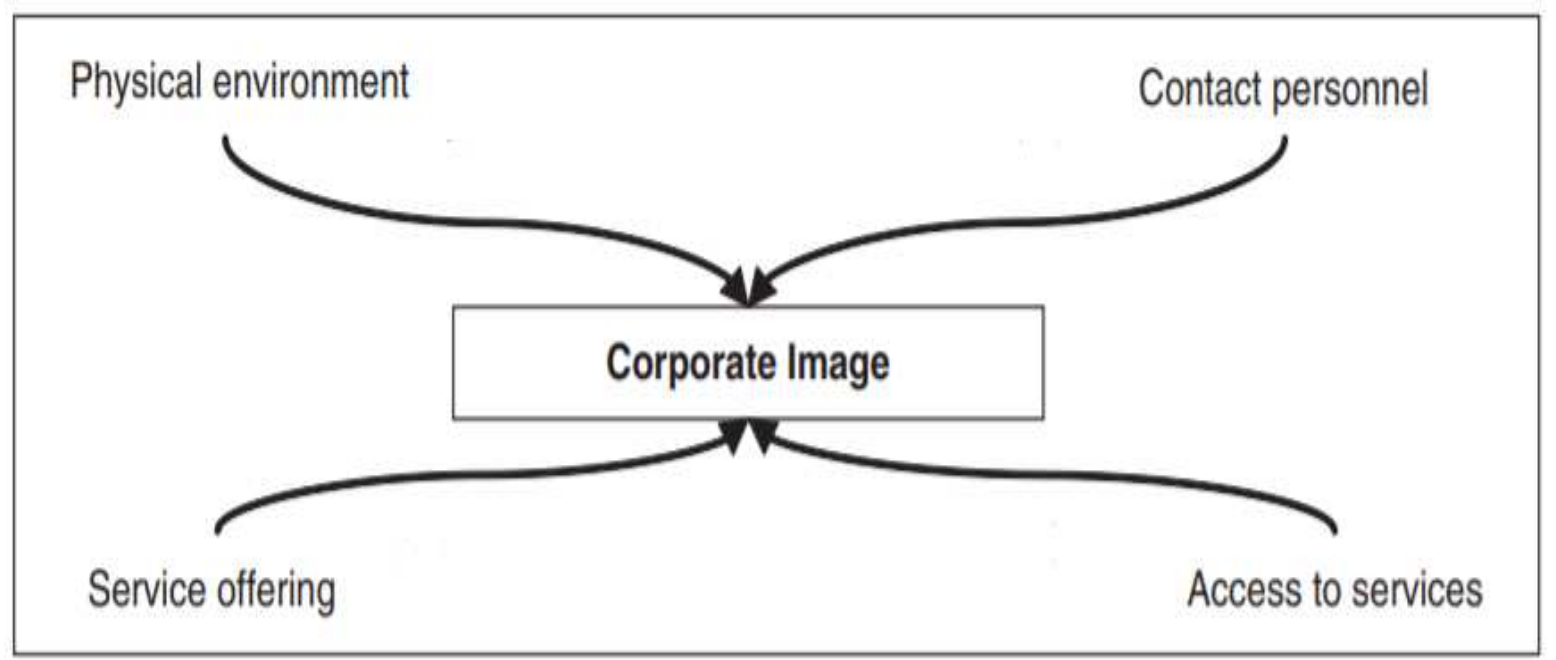

Fig. 2. The model by Tubillejas, Cuadrado, and Frasquet (2011)

Source: Tubillejas, Cuadrado, and Frasquet (2011).

An important aspect in studying the formation of corporate image is the analysis of its components and their impact on the customer attraction. It is interesting to consider the model of the relationship between corporate image and consumers proposed by Gouji, Taghvaei, and Soleimani (2016). The authors singled out elements such as: experience, character, merit, quality, differentiation, price, technology, culture and recognition (Figure 3 ). 


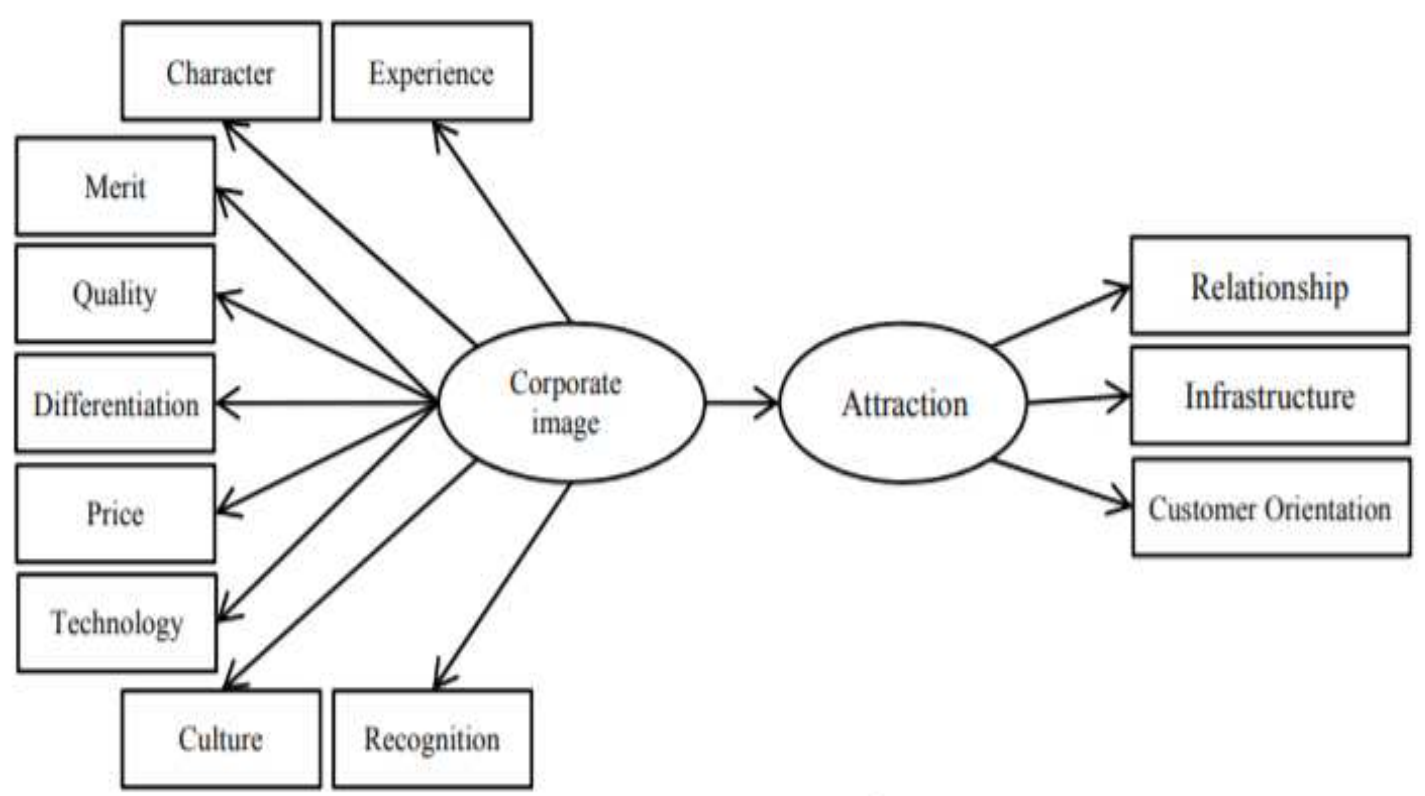

Fig. 3. Relationship between corporate image components and customer attraction

Source: Gouji, Taghvaei, and Soleimani (2016).

There are several areas of behavioral marketing: 1) in relation to employees; 2) in relation to clients; 3 ) in relation to suppliers; 4) in relation to shareholders; 5) in relation to intermediaries. Marketing activities of the organization deployed in these areas result in the shaping a multi-agent system of marketing actors (Inshakov, 2008, pp. 78). This system identifies the features of marketing behavior of the entities that are included in the system of complex multilevel communications with each other, finds out the environment for enhancing the innovation activity of the multi-agency system participants, explores the causes of the opportunism for innovation, and develops economic, organizational, and institutional mechanisms for overcoming (obtaining) opportunistic tendencies, etc. (Ovechkina, 2013). The image is formed according to five areas of behavioral marketing. Figure 4 shows the structure of corporate image of business entities.

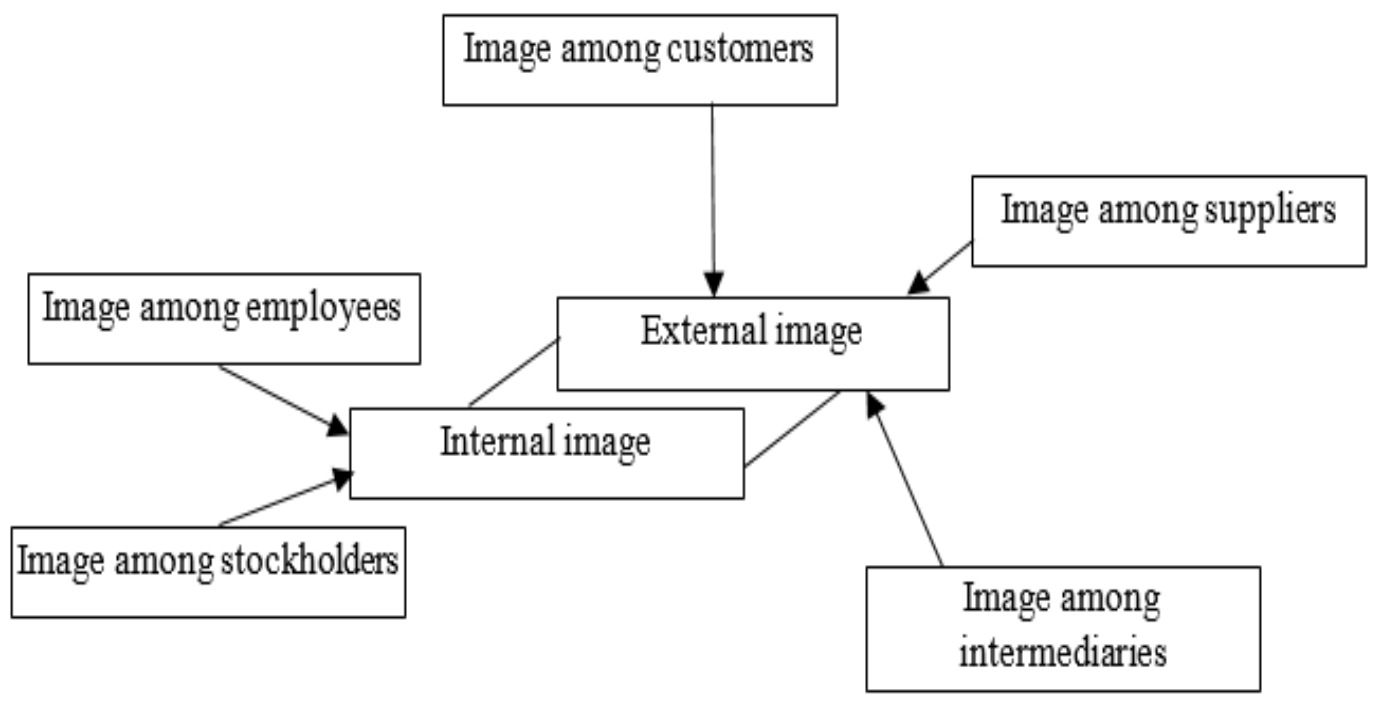

Fig. 4. The structure of business entities' corporate image through behavioral marketing

Source: Compiled by the authors. 
The image of business entities among customers is based on their vision of the unique characteristics that in their view products and services have: quality, design, service and discount system, price, the stated mission and strategy of the bank, as well as its corporate style.

The image of intermediaries and suppliers consists of partner concepts: business reputation, compliance with ethical business practices, reliability, loyalty to partners, information openness, as well as business openness, indicators of which are sales, relative market share, variety of products and services, pricing policy flexibility. They constitute the external image of entrepreneurial structures.

The internal image of business entities is the image of shareholders and employees. The image among shareholders is in shaping their behavior, which depends on the size of financial results, short-term goals of innovation development, market position. The image among employees is formed under the influence of the attitude of managers and owners to their work, interest in personal dates, the availability of social package.

The internal and external image complement each other and not only ensure the advance development of business structures, but also the region and the state.

Corporate image serves as one of the tools to achieve the strategic goals of business entities that relate to the main areas of activities and are oriented towards the future. The formation of a positive image requires purposeful systematic activity related to the transformation of the real image of business entities into a positive one. In order to assess and create a positive corporate image of business entities, it is expedient to consider the "mirror" image, that is, the top management's vision of the corporate image. Since the initiation and resource support for the creation a positive image depends primarily on the leadership, the strategic task is to join the mirror image of business entities and its real image, and then to transform the latter into a positive image that enhances the market power of corporations.

The methodology for shaping the corporate image of business entities can be represented by the following sequence of steps:

1. Analysis of the marketing environment of the corporation and separation of its target (most important for its activities) segments.

2. Shaping the most significant image-generating factors for each target segment.

3. Developing the desired image of business entities (in terms of established strategic goals) for each target segment.
4. Assessing the state of the image of business entities in each target segment.

5. Developing and implementing an activity plan for the positive image formation.

6. Control over the results achieved and adjusting (if necessary) a plan for the positive image formation.

The procedure of creating business entities' corporate image is based on the assumption that image as an instrument of influence on the external environment should be brought closer to the positive one, thus increasing the "market power" of the corporation. Consequently, the parameters characterizing corporate image of business entities must be in line with a positive image.

The following are typical for the internal image of corporations:

- opportunity for advancement;

- salary system and moral incentives;

- level of corporation prestige;

- corporate style;

- moral environment of the corporation;

- staff beliefs about the corporation's mission and strategy;

- the corporation image in the target segments awareness.

The following parameters are for the external image of corporations:

- social events and projects held;

- information openness;

- participation in social programs of the region;

- law-obedience;

- level of loyalty to partners;

- quality and level of service;

- services.

\section{Conclusion}

When creating a positive corporate image, business entities should take into account the five target segments, namely customers, suppliers, shareholders, employees, and intermediaries. Moreover, it should be borne in mind that each of these subjects does not accept rationalist decisions, is an econ who places emphasis on spontaneity, emotionality. Accordingly, it is difficult to predict the situation of creating a positive corporate image of business entities. The latter should create a development strategy using these assumptions, form an approach that creates comfortable environment for cooperation that will be different from rival enterprises. In the 21 st century, characteristic is the retention and conquest of new econs in terms of "spectacles". The "spectacles" can be realized as follows: 
- for clients - discount system, special events, drawing prize contracts on special terms, special terms of consumer lending, etc.;

- for suppliers - long-term cooperation, joint presentations, leisure, conferences, club formation or other thematic institutions;

- for employees (club discount system, the use of various leisure activities not only for employees, but also for their families, bonus system for work in intangible form);
- for shareholders (seminars, conferences);

- for intermediaries (joint financing of large projects, social adaptation, and effective cooperation between the authorities and corporations).

These measures should promote the most ambitious interests of customers, suppliers, employees, shareholders, and intermediaries. All this in aggregate will provide a positive image of business entities not only in domestic markets, but also in the international ones.

\section{References}

1. Ariely, D. (2010). Предсказуемая иррачиональность. Скрытые силы, определяющие наши решения [Predskazuyemaya irratsionalnost. Skrytyye sily, opredeliayushchie nashi resheniya]. Retrieved from http://www.management.com.ua/books/

2. Botha, J. A. R. (2016). A holistic view of the use of corporate culture conveyed by internal marketing for enhancing stability, sustainability and consistency in service quality. Investment Management and Financial Innovations, 13(3-1), 248-257. http://dx.doi.org/10.21511/imfi.13(3-1).2016.11

3. Gouji, R. K., Taghvaei, R., \& Soleimani, H. (2016). The effect of corporate image on the formation of customer attraction. Management Science Letters, 6, 655-670. https://doi.org/10.5267/j.msl.2016.8.003

4. Hashem, T. (2017). Impact of using humor advertisement on airline customers' mental image. Innovative Marketing, 13(3), 25-32. http://dx.doi.org/10.21511/im.13(3).2017.03

5. Inshakov, O. V. (2008). Экономическая генетика как основа наноэкономического анализа [Ekonomicheskay genetika kak osnova nanoekonomicheskogo analiza]. Vestnik VolGU, 1(12), 3, 5-12.

6. Kahneman, D. (1979). Prospect Theory: Decision Making Under Risk. Econometrica, 2, 264.

7. Kehinde, O. A. (2012). Organizational Culture and Its Corporate Image: A Model Juxtaposition. Business and Management Research, 1(1), 121-132. http://dx.doi.org/10.5430/bmr.v1n1p121

8. Ki-Han Chung, Ji-Eun Yu, Myeong-Guk Choi, \& Jae-Ik Shin (2015). The Effects of CSR on Customer Satisfaction and Loyalty in China: The Moderating Role of Corporate Image. Journal of Economics, Business and Management, 3(5), 542-547. https://doi.org/10.7763/joebm.2015.v3.243

9. Kornyliuk, R. (2017). Нобелівська історія - 2017: Річард Тейлер та економіка з людським обличчям [Nobelivska istoriia - 2017: Richard Teiler ta ekonomika z liudskym oblychcham]. Retrieved from https://mind.ua/ru/publications/20177418-nobelevskaya-istoriya-2017-richard-tejler-i-ekonomika-schelovecheskim-licom

10. Korzh, M., Gaievskyi, A., \& Hurdzhyian, K. (2017). Assessment of the enterprise marketing performance. Problems and Perspectives in Management, 15(4), 1-16. http://dx.doi.org/10.21511/ppm.15(4).2017.01

11. Latif, W. B., Islam, Md. A., Noor, I. Md., Mohamad, M., \& Kongsompong, K. (2016). Imagination of brand image for tourism industry. Problems and Perspectives in Management, 14(2-1). https://doi.org/10.21511/ppm.14(2-1).2016.02

12. LeBlanc, G., \& Nguyen, N. (1996). Cues used by customers evaluating corporate image in service firms: An empirical study in financial institutions. International Journal of Service Industry Management, 7(2), 44-56.

13. Mostafa, R. B., Lages, C. R., Shabbir, H. A., \& Thwaites, D. (2015). Corporate Image: A Service Recovery Perspective. Journal of Service Research, 18(4), 468-483. https://doi.org/10.1177/1094670515584146

14. Ovechkina, O. А. (2013). Поведінковий маркетинг учасників мультиагентської системи [Povedinkovyi marketynh uchasnykiv multyahentskoi systemy] (pp. 201-202). Paper presented at Маркетинг інновацій $i$ інновації у маркетингу : збірник тез доповідей VII Міжнародної науково-практичної конференції, 26-28 вересня 2013 p. [Marketynh innovatsii $i$ innovatsii u marketunhu: zbirnyk tez dopovidei VII Mizhnarodnoi naukovo-praktychnoi konferentsii, 26-28 veresnia, 2013.] Sumy: Papirus.

15. Peter, L. (2012). Формирование поведения индивида [Formirovaniye povedeniya individa]. Retrieved from http://do.gendocs.ru/docs/index-72709.html?page=18

16. Richards, Z., Thomas, S. L., Randle, M., \& Pettigrew, S. (2015). Corporate Social Responsibility programs of Big Food in Australia: a content analysis of industry documents. Australian and New Zealand Journal of Public Health, 39(6), 550-556. https://doi.org/10.1111/1753-6405.12429

17. Sallam, M. A. (2016). An Investigation of Corporate Image Effect on WOM: The Role of Customer Satisfaction and Trust. International Journal of Business Administration, 7(3). https://doi.org/10.5430/ijba.v7n3p27

18. Thaler, R. H. (2015). Misbehaving: The Making of Behavioral Economics. New York: W. W. Norton \& Company. 
19. Tubillejas, B., Cuadrado, M., \& Frasquet, M. (2011). A Model of Determinant Attributes of Corporate Image in Cultural Services. Nonprofit and Voluntary Sector Quarterly, 40(2), $356-376$. https://doi.org/10.1177/0899764009344883

20. Van Heerden, C. H. (1999). Developing a corporate image model. SAJEMS, 2(3), 492-508. Retrieved from https://repository.up.ac.za/bitstream/handle/2263/6909/VanHeerden_Developing\%281999\%29.pdf?sequence=1\&i sAllowed $=y$

21. Yong, Z. (2017). The Relationship between Corporate Music and Corporate Image Building. Proceedings of the 2017 7th International Conference on Social Network, Communication and Education (SNCE 2017). Series: Advances in Computer Science Research. https://doi.org/10.2991/snce-17.2017.102

22. Zaiets, M. A., \& Petrova, A. O. (2008). Корпоративний імідж в оптимізації стратегї банківського маркетингу [Korporatyvnyi imidzh v optymizatsii stratehii bankivskoho marketynhu]. Retrieved from http://ena.lp.edu.ua/bitstream/ntb/708/1/122.pdf 